\title{
KEEFEKTIFAN MODEL PEMBELAJARAN BERPIKIR INDUKTIF YANG BERORIENTASI KECERDASAN NATURALIS MELALUI MEDIA FOTO JURNALISTIK DALAM MENINGKATKAN KEMAMPUAN MENULIS PUISI PADA SISWA SMAN 1 GARUT
}

(Studi Eksperimen Kuasi pada Siswa Kelas XII SMAN 1 Garut)

Yulianti

email: yulianti@gmail.com

Guru SMA Negeri 1 Garut

\begin{abstract}
ABSTRAK
Tujuan penelitian ini adalah untuk mengetahui keefektifan model pembelajaran berpikir induktif yang berorientasi pada kecerdasan naturalis melalui media foto jurnalistik dalam meningkatkan kemampuan menulis puisi siswa SMAN 1 Garut. Penelitian ini menggunakan metode eksperimen kuasi terhadap siswa kelas XII SMAN 1 Garut. Data penelitian ini dikumpulkan melalui tes tertulis membuat puisi, lembar observasi, dan skala sikap. Berdasarkan hasil penelitian, dapat disimpulkan bahwa (1) model pembelajaran berpikir induktif yang berorientasi pada kecerdasan naturalis melalui media foto jurnalistik efektif dalam meningkatkan kemampuan menulis puisi siswa SMAN 1 Garut; (2) model pembelajaran berpikir induktif yang berorientasi pada kecerdasan naturalis melalui media foto jurnalistik dapat mempermudah siswa menemukan dan mengembangkan ide dalam membuat puisi.
\end{abstract}

Kata kunci: model berpikir induktif, kecerdasan naturalis, foto jurnalistik

\section{ABSTRACT}

The purpose of this study was to determine the effectiveness of inductive learning model oriented naturalist intelligence through the medium of photojournalism in improving students'ability to write poetry at SMAN 1 Garut. This study used a quasi-experimental method to twelfth grade students of SMAN 1 Garut. The data was collected through a written test to make poetry, observation sheets, and the attitude scale. Based on the results of this study, it can be concluded that (1) inductive learning model oriented naturalist intelligence through the medium of photojournalism is effective in improving students' ability to write poetry at SMAN 1 Garut; (2) inductive learning model oriented naturalist intelligence through the medium of photojournalism can facilitate students to find and develop ideas in making poetry.

Key word: inductive learning model, naturalist intelligence, photojournalism

\section{PENDAHULUAN}

Keterampilan menulis sebagai salah satu keterampilan berbahasa sangat penting dalam dunia pendidikan dari tingkat dasar hingga perguruan tinggi. Kegiatan menulis tidak pernah lepas dilakukan siswa dalam proses belajar-mengajar.

Menurut Sutarno (2008:10) pada dasarnya menulis adalah suatu cara yang tepat untuk mewujudkan, menjabarkan, dan menuangkan ide, konsep, gagasan dan pikiran ke dalam sebuah tulisan. Selanjutnya Sutarno mengemukakan bahwa tulisan seseorang pada dasarnya merupakan rekaman atas penglihatan, pengamatan, pembelajaran, pengalaman, penghayatan, pemaknaan dan pengolahan daya pikir seorang penulis.
Dalam menulis puisi, selama ini ada kesan bahwa menulis puisi sulit, sehingga banyak guru yang hanya mengajarkan apresiasi, tapi tidak menulis puisi (Alwasilah dan Alwasilah, 2007:31).

Demikian juga dengan siswa, mereka umumnya buntu untuk memunculkan gagasan. Selain itu, mereka sulit untuk menentukan diksi dan gaya bahasa yang tepat dalam penulisan puisi sehingga diksi dan gaya bahasa yang dipakai kurang menimbulkan nuansa makna bagi pembaca, tidak puitis, dan sering mengulang kata-kata yang sama.

Pada umumnya dalam pembelajaran puisi, guru biasa menggunakan metode ceramah sehingga siswa akan merasa jenuh dan bosan. 
Oleh karena itu, peneliti mencoba untuk menerapkan model pembelajaran berpikir induktif yang berorientasi kecerdasan naturalis melalui media foto jurnalistik dalam penulisan puisi. Peneliti berasumsi bahwa dengan model tersebut, yaitu siswa mengamati fenomena kerusakan alam melalui media foto jurnalistik, kemudian diekspresikan dengan menggunakan katakata, maka siswa akan menjadi lebih mudah menulis puisi.

Model berpikir induktif merupakan suatu strategi mengajar yang dikembangkan untuk meningkatkan kemampuan siswa dalam mengolah informasi. Model ini merupakan strategi mengajar untuk mengembangkan keterampilan berpikir siswa (Uno, 2010:12).

Proses pembelajaran dalam kompetensi dasar menulis puisi tidak bisa hanya dilakukan melalui kata-kata. Untuk memunculkan ide, dua belahan otak akan terangsang secara bersama-sama jika informasi dikemas dalam bentuk kata-kata (verbal) dan gambar (grafis). Hal ini sejalan dengan pendapat Pasiak (2006: 54) yang mengungkapkan bahwa memori akan tertata dengan baik, efektif, dan efisien jika diformulasikan dalam bentuk kata dan gambar.

Penggunaan media dalam pembelajaran harus dapat menunjang pengelolaan kecerdasan siswa. Howard Gardner (Putra, 2010:10) memperkenalkan tujuh (kemudian menambahkan satu lagi, menjadi delapan) macam kecerdasan. Salah satu kecerdasan yang dapat membekali siswa untuk meraih kesuksesan hidup adalah kecerdasan naturalis. Menurut Gardner dalam Situmorang (2008: 66) bahwa kecerdasan naturalis mencakup keahlian mengenali dan mengategorikan spesies flora dan fauna di lingkungan sekitar. Kecerdasan ini juga meliputi kepekaan terhadap fenomena-fenomena alam lainnya, dan kemampuan membedakan benda-benda tak hidup dengan benda-benda hidup lainnya.

Oleh karena itu, media foto jurnalistik yang akan digunakan dalam pembelajaran menulis puisi adalah foto jurnalistik berbasis kecerdasan naturalis karena dapat membangkitkan kepekaan dan kepedulian siswa terhadap keberlangsungan alam dan membangkitkan kesadaran menjaga lingkungan sekitar.

Berdasarkan uraian di atas, penulis mengambil judul "Keefektifan Model Pembelajaran Berpikir Induktif yang Berorientasi Kecerdasan Naturalis melalui Media Foto Jurnalistik dalam Meningkatkan Kemampuan Menulis Puisi pada Siswa SMAN 1 Garut".

Kajian pustaka; dalam studi ini adalah:

\section{a. Model Pembelajaran Berpikir Induktif}

Model pembelajaran berpikir induktif merupakan karya besar Hilda Taba. Menurut Uno (2010:12) model ini dikembangkan atas dasar beberapa postulat sebagai berikut: (a) Kemampuan berpikir dapat diajarkan; (b) Berpikir merupakan suatu transaksi aktif antara individu dengan data; dan (c) Proses berpikir merupakan suatu urutan tahapan yang beraturan (lawful).

Strategi ini sangat sesuai digunakan untuk social study, juga dalam semua mata pelajaran, seperti sains, bahasa, dan lain-lain. Selain itu, model ini secara tidak langsung dapat mengembangkan kemampuan berpikir kreatif(Uno, 2010:13). Hal ini sejalan dengan pendapat Wahab (2008:66) bahwa model ini dapat diaplikasikan dalam berbagai mata pelajaran guna meningkatkan kemampuan berpikir produktif dan kreatif dan kegunaan model tersebut amat luas. Selanjutnya, Joyce dkk (2009: 116) menyimpulkan struktur model berpikir induktif adalah (1) pembentukan konsep; (2) interpretasi data; dan (3) penerapan prinsip.

\section{b. Kecerdasan Naturalis}

Seiring dengan llmu pengetahuan yang semakin berkembang, konsep inteligensi pun mulai dipandang dengan kaca mata yang lebih 
luas. Pada tahun 1980-an seorang psikolog Harvard, yaitu Howard Gardner (2006: 11) mengelompokkan kecerdasan ke dalam delapan kategori yang terdiri dari kecerdasan linguistik, kecerdasan logis-matematis, kecerdasan spasial, kecerdasan musikal, kecerdasan kinestetik-tubuh, kecerdasan interpersonal, kecerdasan intrapersonal, dan kecerdasan naturalis.

Selanjutnya, Gardner (2003: 33) memiliki keyakinan bahwa semua individu normal memiliki masing-masing kecerdasan tersebut dengan derajat keterampilan dan kombinasi yang berbeda setiap individunya.

Kecerdasan naturalis menurut Gardner (Amstrong, 2013: 7) mencakup kepekaan terhadap fenomena alam. Hal ini sejalan dengan pendapat Uno dan Kuadrat (2009; 14) yang mengungkapkan bahwa kecerdasan naturalis adalah kemampuan seseorang untuk peka terhadap lingkungan alam, misalnya senang berada di lingkungan alam yang terbuka, seperti pantai, gunung, cagar alam, atau hutan. Kecerdasan ini juga berkaitan dengan kecintaan seseorang pada bendabenda alam, binatang, dan tumbuhan.

Selanjutnya, Nurihsan (2007: 76) menjelaskan bahwa intelegensi naturalis merupakan kemampuan seseorang untuk mengenal benda-benda sekitar yang biasanya ditemukan pada ilmuwan dan petualang alam. Ciri-ciri yang menonjol dari orang yang memiliki kecerdasan ini adalah memiliki rasa ingin tahu yang tinggi dan cinta terhadap alam sekitar.

Sementara itu menurut Gunawan (2007: 231) orang yang memiliki kecerdasan naturalis memiliki kriteria mencintai lingkungan/alam, mampu menggolongkan obyek, mengenali, berinteraksi dengan hewan dan tanaman.

Shearer (dalam Nuh, 2011) menjelaskan bahwa orang yang menonjol dalam kecerdasan naturalis menunjukkan rasa empati, pengenalan, dan pemahaman tentang kehidupan dan alam (tanaman, hewan, geologi).

Secara spesifik, Connell (Yaumi, 2012: 200) mendeskripsikan bahwa:

Naturalistic people have a deep interest in the environment. They like to be in nature and they want to protect it from pollution. They can navigate easily in the natural world. They see the patterns in nature, recognize the different flora, fauna, rocks, and bird. As teacher, they bring nature into the classroom and their students outside with more regularity than teachers who are not strong in this intelligence.

\section{c. Foto Jurnalistik}

Salah satu bagian dari fotografi adalah foto jurnalistik yakni foto yang merupakan sajian gambar atau foto yang dapat berdiri sendiri sebagai visualisasi suatu peristiwa

Jenis-jenis Foto Jurnalistik

\begin{tabular}{|c|c|c|}
\hline Yunus & Badan Jurnalistik Dunia & Darmawan \\
\hline a. Spot news & a. Spot photo & a. Foto spot \\
\hline b. General news & b. General news photo & b. Foto feature \\
\hline c. Foto feature & c. People in the news photo & \\
\hline d. Foto esai & d. Daily life photo & \\
\hline & e. Portrait & \\
\hline & f. Sport photo & \\
\hline & g. Science and technology photo & \\
\hline & h. Art and culture photo & \\
\hline & i. Social and environment photo & \\
\hline
\end{tabular}


(Yunus, 2012: 91). Selanjutnya Yunus (2012: 91) mengungkapkan bahwa titik terpenting dalam foto jurnalistik adalah terletak pada proses pemilihan foto yang layak dipublikasikan dalam mendukung pemberitaan. Fotojurnalistik menurut Guru Besar Universitas Missouri, AS, Cliff Edom adalah paduan kata words dan pictures (Alwi, 2008: 4). Sementara itu, menurut Romli (2008: 46) Foto jurnalistik-journalistic photography, photography communications. (1) penyampaian berita, informasi, atau pesan melalui gambar. Fungsinya, antara lain: menginformasikan (to inform), meyakinkan (to persuade), dan menghibur (to entertaint); (2) foto-foto yang mengandung nilai berita atau nilai jurnalistik, yakni aktual, faktual, penting, dan menarik.

Dooley dalam McDaniel (2007:8) berpendapat bahwa "Photojournalism has loosely been defined as everything from freelance fashion photography to daily newspaper press photography". Jadi, yang termasuk ke dalam foto jurnalistik adalah semua bentuk fotografi dari mulai fotografi fashion freelance sampai fotografi harian surat kabar.

\section{d. Menulis Puisi}

Jassin (2002: 40) mengatakan bahwa puisi adalah pengucapan dengan perasaan. Sementara itu, Waluyo (1987: 25) menyatakan bahwa puisi adalah bentuk karya sastra yang mengungkapkan pikiran dan perasaan penyair secara imajinatif dan disusun dengan mengkonsentrasikan semua kekuatan bahasa dengan pengkonsentrasian struktur fisik dan struktur bathinnya.

Menurut Waluyo (1987: 25) puisi terdiri atas dua unsur pokok yakni struktur fisik dan struktur batin. Kedua bagian itu terdiri atas unsur-unsur yang saling mengikat keterjalinan dan unsur itu membentuk totalitas makna yang utuh. Struktur batin puisi terdiri atas tema, nada, perasaan, dan amanat, sedangkan struktur fisik puisi terdiri atas diksi, pengimajian, kata konkret, majas, versifikasi, dan tipografi puisi. Majas terdiri atas lambang dan kiasan, sedangkan versifikasi terdiri atas rima, ritma, dan metrum (Wellek, 1995: 198).

\section{METODE PENELITIAN}

Metode penelitian yang digunakan dalam penelitian ini adalah metode kuasi eksperimen dengan desain pretes-postes kelompok kontrol secara random (The randomized pre-test and post-test control group design). Adapun populasi dalam penelitian ini adalah semua siswa SMAN 1 Garut. Sementara itu, sampel dalam penelitian ini adalah 30 siswa kelas XII IPA 7 dan 30 siswa kelas XII IPA 8 dengan desain sebagai berikut.

$\begin{array}{ccccc}\text { Treatment Group } & \mathrm{R} & \mathrm{O} & \mathrm{X} & \mathrm{O} \\ \text { Control Group } & \mathrm{R} & \mathrm{O} & \mathrm{C} & \mathrm{O} \\ \text { Gambar } & 1 \text { The Randomized Pretest- } \\ \text { Posttest } & \text { Control Group } & \text { Design } \\ \text { (Frankael Dan Wallen, 2007:274). }\end{array}$

Adapun instrumen penelitian yang digunakan peneliti adalah (1) Instrumen pembelajaran yaitu berupa silabus dan rencana pembelajaran yang dijadikan acuan dalam proses belajar mengajar. (2) Instrumen pengumpulan data berupa tes, lembar observasi dan angket.

Langkah-langkah pengolahan data dalam penelitian ini adalah (1) menganalisis hasil tulisan siswa berupa puisi dari setiap aspek yang dinilai, (2) menentukan jumlah hasil skor siswa dari tes awal dan tes akhir pada kelas kontrol dan kelas eksperimen dan mengubahnya ke dalam nilai, (3) uji hipotesis dengan menggunakan uji-t (4) untuk melihat peningkatan kemampuan menulis puisi siswa antara sebelum dan sesudah pembelajaran dihitung dengan rumus $\mathrm{g}$ faktor (gain score ternormalisasi), (5) mengolah data angket siswa.

\section{HASIL PENELITIAN DAN}




\section{PEMBAHASAN}

\section{a. Profil Kemampuan Siswa dalam Menulis Puisi}

Berdasarkan data hasil tes awal pada kelas kontrol, skor yang paling banyak diperoleh siswa dalam aspek diksi, tema, gaya bahasa, keselarasan unsur-unsur puisi, dan tipografi yaitu skor 9 - 11. Hal ini menunjukkan sebagian besar puisi siswa cukup memiliki kemampuan dalam aspek diksi, tema, gaya bahasa, keselarasan unsur-unsur puisi, dan tipografi walaupun penggunaannya belum terdapat pada keseluruhan puisi.

Selanjutnya, skor yang paling banyak diperoleh siswa pada aspek imaji dan rima adalah skor 5-8 (kurang). Hal ini menunjukkan sebagian besar siswa belum dapat menggunakan imaji dan rima dalam puisi sehingga puisi yang ditulisnya belum dapat menghidupkan gambaran (pengalaman inderawi) sesuai dengan foto jurnalistik dan belum dapat menciptakan aspek keindahan permainan bunyi dalam puisi.

Sementara itu, berdasarkan data hasil tes awal pada kelas eksperimen, skor yang paling banyak diperoleh siswa dalam aspek diksi, tema, rima, dan tipografi yaitu skor 9 - 11. Hal ini menunjukkan diksi, tema, rima, dan tipografi yang digunakan siswa sebagian besar sudah cukup tepat digunakan walaupun belum terdapat pada keseluruhan puisi.

Selanjutnya, pada aspek gaya bahasa, imaji, dan keselarasan unsur-unsur puisi, siswa paling banyak mendapatkan skor 5 - 8 (kurang). Hal ini menunjukkan belum cukup banyak gaya bahasa dan imaji yang digunakan dalam puisi serta unsur-unsur yang terdapat dalam puisi siswa belum selaras.

\section{b. Profil Pembelajaran Menulis Puisi di SMAN 1 Garut}

Di kelas XII IPA 7 sebagai kelas kontrol, proses pembelajaran menulis puisi dilakukan dengan menggunakan metode imajinasi. Setelah siswa memahami tentang puisi, guru memperdengarkan alunan musik instrumental yang lembut. Kemudian siswa diminta untuk memejamkan mata menikmati musik. Setelah beberapa saat, siswa diminta untuk berupaya menggambarkan apa yang terlihat dan terdengar, seperti suara angin, suara hujan, kehijauan alam sebagai pemanasan untuk membuka 'mata batin' mereka. Setelah siswa merasa rileks, guru meminta siswa untuk menggambarkan pengalaman/ peristiwa yang pernah mereka lihat atau dengar yang bertema kerusakan alam yang berhubungan dengan pembalakan liar. Ketika siswa sedang menggambarkan imajinya, guru memberikan waktu agar siswa dapat membangun imaji visual mereka sendiri. Guru kemudian memberikan beberapa pertanyaan dan pernyataan untuk membantu keutuhan gambaran imaji visual siswa.

Setelah cukup, pengarahan imaji diakhiri. Siswa kemudian saling berbagi pengalaman imaji mereka dengan teman kelompoknya. Selanjutnya, siswa dipersilakan untuk menulis puisi secara individual berdasarkan pengalaman imaji mereka masing-masing.

\section{c. Deskripsi Proses Pembelajaran Menulis Puisi dengan Menggunakan Model Berpikir Induktif yang Berorientasi Kecerdasan Naturalis melalui Media Foto Jurnalistik}

Proses penelitian dilakukan di kelas XII IPA 8 yang dijadikan kelas eksperimen. Pembelajaran dilakukan dengan menggunakan model pembelajaran berpikir induktif yang berorientasi kecerdasan naturalis melalui media foto jurnalistik. Model pembelajaran ini terdiri atas tiga tahap yakni tahap penemuan konsep, tahap interpretasi data, dan tahap penerapan prinsip.

Tahap penemuan konsep dimulai dengan kegiatan guru mengelompokkan siswa yang terdiri dari tiga siswa per kelompok. Guru kemudian memberikan contoh puisi yang bertema alam. Secara berkelompok, siswa mengamati contoh puisi tersebut dalam 
beberapa menit sambil mendiskusikan mengenai isi, bentuk puisi dan unsur-unsur kecerdasan naturalis yang terdapat dalam puisi tersebut. Setelah itu, guru mengajak siswa untuk mendiskusikan isi, bentuk puisi dan unsur-unsur kecerdasan naturalis yang terdapat dalam puisi tersebut. Masingmasing kelompok, melalui perwakilannya, mengomunikasikan hasil temuan mereka mengenai isi, bentuk puisi dan unsur-unsur kecerdasan naturalis yang terdapat dalam puisi tersebut secara bebas. Selanjutnya, guru mengarahkan temuan-temuan siswa ke dalam unsur-unsur puisi yang lebih spesifik lagi, yaitu diksi, tema, gaya bahasa, imaji, rima, dan tipografi serta unsurunsur kecerdasan naturalis sehingga siswa mendapat gambaran yang lebih jelas tentang unsur-unsur yang harus diperhatikan ketika akan menulis puisi. Setelah siswa memahami tentang puisi dan unsur-unsur kecerdasan naturalis, guru membagikan kembali foto jurnalistik. Siswa mengamati foto jurnalistik tersebut secara berkelompok dalam beberapa menit. Selanjutnya siswa diminta untuk mengidentifikasi data yang mengandung unsur kecerdasan naturalis yang terdapat dalam foto jurnalistik. Data tersebut berupa kata-kata/frase/kalimat yang menunjukkan empati, rasa cinta, dan tanggung jawab terhadap alam. Data tersebut kemudian dikelompokkan sesuai dengan kemiripan dan karakteristik tertentu. Setelah itu, guru meminta siswa untuk memberi label atau membuat kategorisasi terhadap data-data yang mengandung unsur kecerdasan naturalis yang telah dikelompokkan.

Tahap selanjutnya adalah tahap interpretasi data. Pada tahap ini, secara berkelompok siswa melaporkan hasil diskusinya mengenai data-data yang mengandung unsur kecerdasan naturalis yang terdapat dalam media foto jurnalistik. Dalam diskusi kelas, siswa lain menanggapi laporan temannya. Guru meminta siswa untuk meninjau kembali pengelompokkan yang telah dilakukan. Kemudian, guru meminta siswa untuk menghubung-hubungkan fakta yang mengandung unsur kecerdasan naturalis yang terdapat dalam foto jurnalistik tersebut. Guru membimbing siswa untuk menarik kesimpulan dari fakta-fakta yang mengandung unsur kecerdasan naturalis yang terdapat dalam foto jurnalistik tersebut.

Tahap terakhir yaitu tahap penerapan prinsip. Pada tahap ini, guru membimbing siswa untuk menerapkan kesimpulan yang telah mereka buat mengenai puisi dan kecerdasan naturalis terhadap permasalahan alam yang sesuai dengan foto jurnalistik tersebut dalam sebuah puisi bertema alam. Selanjutnya, siswa mengembangkan puisi masing-masing sesuai data, fakta, dan kesimpulan yang telah didiskusikan bersama. Pengembangan puisi dilakukan secara individual tetapi siswa masih boleh bekerja sama dengan teman dalam kelompoknya.

\section{d. Keefektifan Model Pembelajaran Berpikir Induktif yang Berorientasi pada Kecerdasan Naturalis Melalui Media Foto Jurnalistik dalam Meningkatkan Kemampuan Menulis Puisi}

Pembelajaran menulis puisi, baik dengan menggunakan model pembelajaran berpikir induktif yang berorientasi pada kecerdasan naturalis maupun model pembelajaran imajinatif mengalami peningkatan kemampuan dalam menulis puisi. Peningkatan hasil tes kemampuan menulis puisi di kelas eksperimen yang menggunakan model pembelajaran berpikir induktif yang berorientasi pada kecerdasan naturalis lebih tinggi dibanding peningkatan hasil tes kemampuan menulis puisi di kelas kontrol yang menggunakan model pembelajaran imajinatif. Hal ini bisa dilihat dari peningkatan kelas eksperimen sebesar 22,54, sedangkan kelas kontrol sebesar 8,49.

Berdasarkan hasil pengolahan data, diperoleh bahwa nilai signifikansi uji Shapiro-Wilk 
data pretes pada kelas eksperimen 0,681, lebih besar dari $\alpha=0,05$ dan pada kelas kontrol adalan 0,784, lebih besar dari $\alpha=$ 0,05 . Nilai signifikansi kedua kelas tersebut lebih besar dari 0,05. Hal ini menunjukkan bahwa data pretes yang diperoleh dari kelas eksperimen dan kelas kontrol berdistribusi normal. Sementara itu, uji homogenitas nilai tes awal kelas eksperimen dan kelas kontrol diperoleh angka signifikansi based on mean $=0,351$. Karena angka signifikansi lebih besar dari 0,05, data pretes kelas eksperimen maupun kelas kontrol bersifat homogen atau memiliki varians yang sama.

Adapun dari hasil uji kesamaan dua rata-rata di kelas eksperimen dan kontrol, diperoleh angka signifikansi $=0,24$. Karena angka signifikansi lebih besar dari 0,05, maka $\mathrm{H}_{0}$ diterima. Dengan kata lain, kemampuan awal siswa dalam menulis puisi pada kedua kelas (eksperimen dan kontrol) adalah sama.

Selanjutnya, dari hasil uji normalitas data tes akhir di kelas aksperimen dan kontrol diperoleh data bahwa nilai signifikansi untuk uji Shapiro-Wilk kelas eksperimen dan kelas kontrol masing-masing adalah 0,038 dan 0,913. Nilai signifikansi untuk kelas eksperimen kurang dari 0,05 dan kelas kontrol lebih besar dari 0,05. Hal ini menunjukkan bahwa data postes yang diperoleh dari kelas eksperimen dan kelas kontrol berasal dari populasi yang tidak berdistribusi normal. Berdasarkan uji normalitas tersebut, dapat diambil kesimpulan bahwa kedua sampel tidak berdistribusi normal.

Adapun uji kesamaan dua rata-rata dengan menggunakan uji nonparametrik diperoleh hasil nilai sig. (2-tailed) 0,000. Karena nilai probabilitas $0,00<0,05$ maka $\mathrm{H}_{0}$ ditolak dan $\mathrm{H}_{1}$ diterima. Dapat disimpulkan bahwa terdapat perbedaan secara signifikan dalam kemampuan menulis puisi siswa pada tes akhir dengan menggunakan model pembelajaran berpikir induktif yang berorientasi pada kecerdasan naturalis melalui media foto jurnalistik lebih baik daripada siswa yang belajar menggunakan metode imajinasi.

Selanjutnya, dari hasil uji normalitas gain ternormalisasi hasil kemampuan menulis puisi siswa kelas eksperimen dan kelas kontrol diperoleh data bahwa nilai signifikansi untuk uji Shapiro-Wilk kelas eksperimen dan kelas kontrol masing-masing adalah 0,495 dan 0,690. Nilai signifikansi untuk kelas eksperimen dan kelas kontrol lebih besar dari 0,05. Hal ini menunjukkan bahwa data gain ternormalisasi yang diperoleh dari kelas eksperimen dan kelas kontrol berasal dari populasi yang berdistribusi normal. Berdasarkan uji normalitas tersebut, dapat diambil kesimpulan bahwa kedua sampel berdistribusi normal.

Sementara itu, berdasarkan hasil uji homogenitas gain ternormalisasi hasil kemampuan menulis puisi siswa kelas eksperimen dan kelas kontrol diperoleh angka signifikansi based on mean $=0,015$. Karena angka signifikansi lebih kecil dari 0,05 , gain ternormalisasi kelas eksperimen maupun kelas kontrol bersifat tidak homogen atau memiliki varians yang berbeda.

Kemudian, berdasarkan hasil uji beda rata-rata gain ternormalisasi kemampuan menulis puisi siswa kelas kontrol dan kelas eksperimen terlihat bahwa nilai sig. (2-tailed) 0,000. Jadi, sig. 1 tailed $=\operatorname{sig} 2$ tailed $/ 2=0,00 / 2=0,00,<0,05$. Karena nilai probabilitas $0,00<0,05$ maka $\mathrm{H}_{0}$ ditolak dan $\mathrm{H}_{1}$ diterima. Dapat disimpulkan bahwa terdapat perbedaan secara signifikan dalam peningkatan kemampuan menulis puisi dengan menggunakan model pembelajaran berpikir induktif yang berorientasi pada kecerdasan naturalis melalui media foto jurnalistik daripada siswa yang belajar menggunakan metode imajinasi. 


\section{e. Analisis dan Deskripsi Respons} Siswa terhadap Proses Pembelajaran Menulis Puisi dengan Menggunakan Model Berpikir Induktif yang Berorientasi Kecerdasan Naturalis Melalui Media Foto Jurnalistik.

Berdasarkan hasil angket, diketahui bahwa pada umumnya siswa memberikan tanggapan positif terhadap model pembelajaran berpikir induktif yang berorientasi kecerdasan naturalis melalui media foto jurnalistik dalam pembelajaran menulis puisi. Hal ini terlihat dari jawaban siswa yang sebagian besar $(72,22 \%)$ berkonsentrasi mengikuti pembelajaran bahasa Indonesia, 66,67\% menyatakan bersemangat mengikuti kegiatan menulis puisi, $61,11 \%$ menyatakan pembelajaran menulis puisi dengan menggunakan model berpikir induktif yang berorientasi padakecerdasan naturalis melalui media foto jurnalistik dapat memunculkan imajinasi dan gagasan dalam menulis puisi, bahkan 55,56\% menyatakan pembelajaran menulis puisi dengan menggunakan model berpikir induktif yang berorientasi pada kecerdasan naturalis melalui media foto jurnalistik mempermudah mereka untuk mengembangkan ide ke dalam kata-kata puitis. Selain itu, 77,78\% siswa menyatakan mereka tidak kesulitan dalam menulis puisi melalui model berpikir induktif yang dibantu oleh media foto jurnalistik.

\section{KESIMPULAN}

Terdapat perbedaan peningkatan kemampuan siswa dalam menulis puisi antara siswa yang pembelajarannya menggunakan model berpikir induktif yang berorientasi pada kecerdasan naturalis melalui media foto jurnalistik dengan siswa yang menggunakan metode imajinasi. Siswa di kelas eksperimen yang pembelajarannya model berpikir induktif yang berorientasi pada kecerdasan naturalis melalui media foto jurnalistik mengalami peningkatan yang lebih tinggi daripada anak di kelas kontrol yang pembelajaranya menggunakan metode imajinasi. Sementara itu, hasil observasi selama penerapan model berpikir induktif yang berorientasi pada kecerdasan naturalis melalui media foto jurnalistik berlangsung sangat baik. Hal tersebut dapat terlihat dari aktivitas siswa dan guru dalam setiap pertemuan di kelas eksperimen.

Berdasarkan hasil angket pendapat siswa terhadap perlakuan yang diberikan dengan menggunakan model pembelajaran berpikir induktif yang berorientasi pada kecerdasan naturalis, keberterimaan siswa cenderung baik.

\section{DAFTAR PUSTAKA}

Alwasilah, A. Chaedar dan Senny Suzanna Alwasilah. 2007. Pokoknya Menulis-Cara Baru Menulis dengan Metode Kolaborasi. Bandung: PT Kiblat Buku Utama.

Alwi, Audy Mirza. 2008. Foto Jurnalistik, Metode Memotret dan Mengirim Foto ke Media Massa. Jakarta: PT Bumi Aksara.

Amstrong, Thomas. 2013. Kecerdasan Multipel di dalam Kelas. Edisi Ketiga (Terjemahan). Jakarta: PT Indeks.

Gunawan, Adi W. 2007. Genius Learning Strategy, Petunjuk Praktis untuk Menerapkan Accelerated Learning. Jakarta: PT Gramedia Pustaka Utama.

Jassin, H. B. 2002. Kesusastraan Indonesia Modern dalam Kritik dan Esei III. Jakarta: Gramedia.

Joyce, Bruce, Marsha Weil \& Emily Calhoun. 2009. Models of Teaching. (Edisi Kedelapan, Terjemahan Achmad Fawaid \& Ateilla Mirza). Yogyakarta: Pustaka Pelajar.

McDaniel, Kyle Ross. 2007. Reviewing The Image of The Photojournalism in Film: How Ethical Dilemmas Shape Stereotypes of The onScreen Press Photographer in Motion Pictures from 1954 to 2006. A thesis presented to the Faculty of the Graduate School University of Missouri-Columbia.

Nurihsan, Achmad Juntika. 2007. Strategi Layanan Bimbingan dan Konseling. Bandung: PT Refika Aditama. 